\title{
PROFITABILITAS, RISIKO KEUANGAN DAN NILAI PERUSAHAAN, DAN PRAKTIK PERATAAN LABA
}

\author{
Feby Lutfitasari \\ Novrida Qudsi Lutfillah \\ Universitas Wijaya Putra \\ vridaoayu@gmail.com
}

\begin{abstract}
The research purpose is to test the partial and simultaneous effect of the variabel of profitability, financial risk, and firm value to the income smoothing practices. This research is done by quantitative approach upon the companies registered in BEI for 2013-2015 periods. The results showed that there was no significant influence partially and simultaneously variable profitability, financial risk and corporate value to the practice of income smoothing.
\end{abstract}

Key word: Income smoothing, Profitability, Financial Risk, Firm Value

\section{PENDAHULUAN}

Laporan keuangan selama ini dipakai sebagai informasi dalam menilai kemampuan manajemen dalam mencapai sasaran utama perusahaan (Atarwaman, 2011). Dalam hal ini, Informasi laba merupakan komponen utama yang menjadi perhatian para pemakai informasi laporan keuangan. Pentingnya informasi laba menjadikan pihak manajemen cenderung menampilkan performa terbaik perusahaan yang dituangkan dalam laporan keuangan (Pratiwi dan Handayani, 2014). Adanya Standar akuntansi keuangan (SAK) sebagai dasar dalam membuat laporan keuangan, memberikan kekuasaan bagi manajemen dalam memilih kebijakan akuntansi. Fleksibilitas ini menyebabkan manajemen cenderung melakukan perilaku yang tidak semestinya yaitu dengan melakukan praktik perataan laba (Prayudi dan Daud, 2013).

Perataan laba didefinisikan sebagai cara yang digunakan manajemen untuk mengurangi fluktuasi laba yang dilaporkan baik secara artifisial maupun secara riil (Setyani dan Liffa, 2012). Motif manajemen melakukan manajemen laba disebabkan untuk menjaga nilai laba yang stabil dibandingkan nilai laba yang cenderung bergejolak (volatile). Kondisi ini menyebabkan manajemen akan bertindak menaikkan laba yang dilaporkan jika jumlah laba yang sebenarnya menurun dari laba tahun sebelumnya dan sebaliknya manajemen akan memilih untuk menurunkan laba yang dilaporkan jika laba yang sebenarnya meningkatkan dibandingkan laba tahun sebelumnya (Aji dan Mita, 2010; Pratiwi dan Handayani, 2014). Tujuan dilakukannya perataan laba adalah untuk memberikan rasa aman kepada investor karena kemungkinan fluktuasi laba yang kecil dan meningkatkan kemampuan investor untuk meramalkan laba perusahaan pada periode mendatang (Abiprayu dan Irene, 2011).

Praktik perataan laba tidak terlepas dari beberapa faktor yang mempengaruhinya. Dalam beberapa penelitian sebelumnya, Faktor pertama yang diduga berpengaruh terhadap praktik perataan laba adalah tingkat profitabilitas. Budiasih (2009) menyimpulkan bahwa profitabilitas memiliki pengaruh yang positif dan signifikan terhadap praktik perataan laba. Faktor lain yang diduga berpengaruh terhadap manajemen laba adalah risiko keuangan. Bitner dan Dolan (2010) mengemukakan bahwa perusahaan yang memiliki risiko keuangan yang tinggi akan menyebabkan manajemen cenderung untuk tidak melakukan manajemen laba karena perusahaan tidak ingin berbuat sesuatu yang membahayakan di dalam jangka panjang. Nilai perusahaan merupakan salah satu faktor yang mempengaruhi praktik perataan laba. Penelitian Prayudi dan Daud (2013) menunjukkan bahwa semakin besar nilai perusahaan maka akan semakin besar kecenderungan perusahaan melakukan manajemen laba, hal ini dikarenakan manajemen ingin menarik minat calon investor, karena investor cenderung melihat nilai perusahaan sebelum berinvestasi. 
Hasil penelitian terhadap praktik perataan laba yang dilakukan oleh peneliti sebelumnya masih ditemukan hasil yang berbeda-beda, sehingga peneliti tertarik untuk meneliti kembali mengenai praktik perataan laba. Berdasarkan penjelasan tersebut, penelitian ini bertujuan menguji pengaruh profitabilitas, risiko keuangan dan nilai perusahaan baik secara parsial maupun simultan terhadap praktik perataan laba.

\section{TINJAUAN PUSTAKA DAN HIPOTESIS \\ 2.1. Perataan Laba}

Salah satu konsep perataan laba dapat dijelaskan yakni dengan menggunakan pendekatan teori keagenan. Teori keagenan menekankan bahwa angka-angka akuntansi memainkan peranan penting dalam menekankan konflik antara pemilik perusahaan dan pengelolannya atau manajer. Teori agensi memiliki asumsi bahwa tiap-tiap individu semata-mata termotivasi oleh kepentingan dirinya sendiri sehingga menimbulkan konflik kepentingan antara principal dan agent (Noviana dan Yuyetta, 2011). Konflik kepentingan semakin meningkat terutama karena principal tidak dapat memonitor kepentingan agen sehari-hari. Agent mempunyai lebih banyak informasi mengenai kapasitas diri, lingkungan kerja, dan perusahaan secara keseluruhan. Hal ini menyebabkan ketidakseimbangan informasi (asimetri informasi). Asimetri informasi dan konflik kepentingan yang terjadi akan mendorong agen untuk menyajikan informasi yang tidak sebenarnya kepada principal terutama jika informasi tersebut berkaitan dengan pengukuran kinerja.

Watt dan Zimmerman (1986) menjelaskan ada tiga hipotesis yang diaplikasikan untuk melakukan prediksi dalam teori akuntansi positif mengenai motivasi manajemen melakukan perataan laba, yaitu: (1) Hipotesa rencana bonus (bonus plan hypothesis), (2) Hipotesa perjanjian utang (debt covenant hypothesis), dan (3) Hipotesa biaya politik (political cost hypothesis). Widodo (2011) mengemukakan bahwa alasan dilakukannya perataan laba bertujuan untuk memperbaiki hubungan dengan kreditur, investor, dan karyawan serta meratakan siklus bisnis melalui proses psikologis dengan cara: (1) Mengurangi total pajak yang dibayarkan oleh perusahaan, (2) Meningkatkan kepercayaan investor terhadap perusahaan karena laba yang stabil akan mendukung kebijakan pembayaran deviden yang stabil, (3) Meningkatkan hubungan antara manajer dan karyawan karena pelaporan laba yang meningkat tajam memeberi kemungkinan munculnya tuntutan kenaikan gaji atau upah, dan (4) Siklus peningkatan dan penurunan laba dapat ditandingkan dan gelombang optimisme dan pesimisme dapat diperlunak.

\subsection{Profitabilitas}

Profitabilitas adalah kemampuan perusahaan memperoleh laba dalam hubungannya dengan penjualan, total asset maupun modal sendiri (Sartono, 2010). Rasio profitabilitas adalah ukuran mengenai kemampuan perusahaan dalam menghasilkan keuntungan selama periode tertentu. Dalam rasio profitabilitas ini dapat dikatakan sampai sejauh mana keefektifan dari keseluruhan manajemen dalam menciptakan keuntungan bagi perusahaan. Penelitian Amanza (2012) menyimpulkan bahwa profitabilitas yang menurun memiliki kecenderungan untuk melakukan tindakan perataan laba agar laba tampak stabil. Profitabilitas mencerminkan kemampuan perusahaan dalam menghasilkan laba atas pengelolaan aset perusahaan yang merupakan perbandingan antara earning after tax dengan total asets.

\subsection{Risiko Keuangan}

Brigham dan Houston (2011:164) menjelaskan bahwa risiko keuangan merupakan suatu tambahan risiko bagi pemegang saham biasa yang diakibatkan oleh penggunaan leverage keuangan. Leverage keuangan mengacu pada penggunaan sekuritas yang memberikan penghasilan tetap (hutang dan saham preferen). Semakin tinggi nilai leverage maka risiko yang akan dihadapi investor akan semakin tinggi dan para investor akan meminta keuntungan yang semakin besar. Leverage dalam Van Horne (2007:182) adalah penggunaan biaya tetap dalam 
usaha untuk meningkatkan profitabilitas. Leverage merupakan pedang bermata dua menurut Van Horne (2007:182) yang mana jika laba perusahaan dapat diperbesar, maka begitu pula dengan kerugiannya. Dengan kata lain, penggunaan leverage dalam perusahaan bisa saja meningkatkan laba perusahaan, tetapi bila terjadi sesuatu yang tidak sesuai harapan, maka perusahaan dapat mengalami kerugian yang sama dengan persentase laba yang diharapkan, bahkan mungkin saja lebih besar.

\subsection{Nilai Perusahaan}

Nilai perusahaan dapat diartikan sebagai kemampuan perusahaan dalam memaksimumkan kemakmuran pemegang saham. Nilai perusahaan dapat dicerminkan dalam harga saham perusahaan. Memaksimalkan nilai perusahaan berarti juga memaksimalkan kemakmuran pemegang saham yang merupakan tujuan utama perusahaan. Aji dan Mita (2010) mengemukakan apabila suatu perusahaan dapat mempertahankan perbandingan nilai rasio antar nilai pasar dengan nilai buku ekuitas perusahaan lebih besar dari satu, maka perusahaan dapat menarik arus sumber daya ke dalam perusahaan.

Peningkatan nilai perusahaan dapat menggambarkan kesejahteraan pemilik perusahaan, sehingga pemilik perusahaan akan mendorong manajer agar bekerja lebih keras dengan menggunakan insensif untuk memaksimalkan nilai perusahaan. Suharli (2006) menyatakan bahwa nilai pemegang saham akan meningkat apabila nilai perusahaan meningkat yang ditandai dengan tingkat pengembalian investasi yang tinggi kepada pemegang saham. Nilai perusahaan diukur dari nilai pasar wajar dari harga saham. Bagi perusahaan yang sudah go public maka nilai pasar wajar perusahaan ditentukan mekanisme permintaan dan penawaran di bursa, yang tercermin dalam listing price. Harga pasar merupakan cerminan berbagai keputusan dan kebijakan manajemen.

\subsection{Hipotesis Penelitian}

\subsubsection{Pengaruh Profitabilitas terhadap Praktik Perataan Laba}

Profitabilitas yang diukur dalam skala rasio menggunakan return on Asset. Aji dan Mita (2010) juga mengatakan semakin tinggi tingkat profitabilitas maka perusahaan akan cenderung untuk tidak melakukan perataan laba karena perusahaan tersebut akan semakin menjadi sorotan publik, sehingga perusahaan kemungkinan berusaha untuk tidak melakukan tindakan yang membahayakan kredibilitas perusahaan. Dari penjelasan di atas, maka hipotesis yang dapat dirumuskan adalah:

H1: Profitabilitas berpengaruh negatif terhadap praktik perataan laba yang dilakukan oleh perusahaan.

\subsubsection{Pengaruh Resiko Keuangan terhadap Praktik Perataan Laba}

Risiko keuangan adalah perbandingan antara hutang dan aktiva yang menunjukkan berapa bagian aktiva yang digunakan untuk menjamin hutang. Ukuran ini berkaitan dengan ketat atau tidaknya suatu persetujuan utang. Dalam penelitian Cahyani (2012) menyatakan bahwa adanya pengaruh risiko keuangan terhadap perataan laba. Hal ini menyatakan bahwa semakin tinggi risiko keuangan maka perusahaan semakin cenderung untuk melakukan praktik perataan laba. Dari penjelasan di atas, maka hipotesis yang dapat dirumuskan adalah:

H2: Risiko keuangan berpengaruh positif terhadap praktik perataan laba yang dilakukan perusahaan.

\subsubsection{Pengaruh Nilai Perusahaan terhadap Praktik Perataan Laba}

Aji dan Mita (2010) juga menyimpulkan bahwa, semakin tinggi nilai perusahaan maka perusahaan akan cenderung melakukan praktek perataan laba. Dengan melakukan perataan laba, variabilitas laba yang minim itulah yang berusaha dipertahankan oleh perusahaan agar disukai 
oleh investor, karena nilai perusahaan yang stabil merupakan salah satu hal yang dipertimbangkan investor untuk membuat keputusan investasi. Dari penjelasan di atas, maka hipotesis yang dapat dirumuskan adalah:

H3: Nilai perusahaan berpengaruh positif terhadap praktik perataan laba yang dilakukan perusahaan.

\subsubsection{Pengaruh Profitabilitas, RIsiko Keuangan dan Nilai Perusahaan terhadap Praktik Perataan Laba}

Banyak faktor-faktor yang mempengaruhi praktik perataan laba, salah satunya Profitabilitas di mana profitabilitas memberikan gambaran tentang efektivitas pengelolaan perusahaan. Sedangkan risiko Keuangan digunakan untuk perbandingan antara hutang dan aktiva. Yang menunjukkan bagian aktiva yang digunakan untuk menjamin hutang. Dan nilai perusahaan menyimpulkan perusahaan yang nilai pasar yang tinggi akan cenderung untuk melakukan perataan laba, hal ini dikarenakan perusahaan akan cenderung menjaga konsistensi labanya agar nilai pasar perusahaan tetap tinggi sehingga dapat lebih menarik arus sumber daya ke dalam perusahaannya. Prayudi dan Daud (2013) yang menyimpulkan adanya hubungan signifikan secara simultan profitabilitas, risiko keuangan dan nilai perusahaan terhadap praktik perataan laba. Maka hipotesis yang dirumuskan adalah:

H4: Profitabilitas, Resiko Keuangan dan Nilai Perusahaan secara simultan mempunyai pengaruh signifikan terhadap praktik perataan laba.

\section{METODE PENELITIAN}

Pendekatan yang digunakan dalam penelitian ini adalah pendekatan kuantitatif (positivism) yang berbentuk asosiatif, $\mathrm{d}$ imana tujuan penelitian ini untuk mengetahui pengaruh antara dua variabel atau lebih. Jenis penelitian ini adalah penelitian eksplanatori dengan menggunakan data sekunder, data yang pengumpulannya dan pengolahannya dilakukan oleh pihak lain yakni diperoleh dari website www.idx.co.id. Penelitian ini dilakukan pada perusahaan-perusahaan manufaktur yang go publik di Bursa Efek Indonesia periode 2013-2015.

Populasi dari penelitian ini adalah seluruh perusahaan manufaktur yang terdaftar di Bursa Efek Indonesia tahun 2013-2015 yang berjumlah 193 perusahaan. Metode pengambilan sampel dalam penelitian ini adalah purposive sampling. Berdasarkan seleksi yang dilakukan, diperoleh 45 perusahaan sebagai sampel penelitian dengan kriteria yang tampak pada Tabel 1.

Tabel 1. Prosedur Pemilihan Sampel

\begin{tabular}{lc}
\hline \multicolumn{1}{c}{ Kriteria Sampel } & $\begin{array}{c}\text { Jumlah observasi } \\
\text { (Perusahaan) }\end{array}$ \\
\hline $\begin{array}{l}\text { Perusahaan yang termasuk ke dalam industri manufaktur selama } \\
\text { periode 2013-2015 }\end{array}$ & 193 \\
$\begin{array}{l}\text { Perusahaan yang laporan keuangannya tidak dinyatakan dalam } \\
\text { Rupiah (Rp) }\end{array}$ & $(165)$ \\
$\begin{array}{l}\text { Perusahaan yang tidak mempublikasikan laporan keuangan per 31 } \\
\text { Desember } \\
\text { Terpilih sebagai sampel }\end{array}$ & $(13)$ \\
Total pengamatan $=$ (sampel x n-tahun) & $\begin{array}{c}15 \\
15 \times 3 \text { tahun }=45 \\
\text { sampel }\end{array}$ \\
\hline
\end{tabular}

Penelitian ini menggunakan 4 (empat) variabel yang terdiri dari profitabilitas, risiko keuangan dan nilai perusahaan, dan praktik perataan laba. Profitabilitas diukur dengan menggunakan proksi Return on Asset (ROA). Pengukuran menggunakan ROA karena rasio ini memberikan ukuran yang lebih baik atas profitabilitas perusahaan karena menunjukkan 
efektivitas manajemen dalam menggunakan aktiva untuk memperoleh keuntungan. ROA diperoleh dari hasil bagi laba bersih perusahaan terhadap nilai buku total aset perusahaan (Sudana, 2011).

Risiko keuangan diukur menggunakan rasio leverage. Menurut Abiprayudan Irene (2011) risiko keuangan adalah tambahan risiko yang dibebankan kepada para pemegang saham biasa sebagai hasil dari keputusan untuk mendapatkan pendanaan melalui hutang. Leverage berguna untuk menunjukkan kualitas kewajiban perusahaan serta berapa besar perbandingan antara kewajiban tersebut dengan aktiva perusahaan. Selanjutnya, nilai perusahaan diukur dengan menggunakan PBV (Price to Book Value), merupakan merupakan rasio pasar yang digunakan untuk mengukur kinerja harga pasar saham terhadap nilai bukunya (Aji dan Mita, 2010). Rasio ini menunjukkan seberapa jauh suatu perusahaan mampu menciptakan nilai perusahaan yang relatif terhadap jumlah modal yang diinvestasikan.

Perataan laba merupakan tindakan meratakan earnings yang dilaporkan sebagai pengurangan secara sengaja fluktuasi di sekitar earnings tertentu yang dianggap normal bagi sebuah perusahaan. Pengukuran perataan laba menggunakan Indeks Eckel. Indeks Eckel digunakan untuk mengindikasikan perusahaan melakukan perataan laba atau tidak. Adapun ukuran indeks Eckel sebagai berikut:

$$
\mathrm{I} \leq \frac{\mathrm{CV} \Delta \mathrm{S}}{\mathrm{CV} \Delta \mathrm{I}}
$$

Keterangan :

I = Indeks Eckel

$\mathrm{CV}=$ Koefisien variasi dari variabel, yaitu standar deviasi dibagi dengan nilai yang diharapkan

$\Delta \mathrm{S}=$ Perubahan pendapatan dalam suatu periode

$\Delta \mathrm{I}=$ Perubahan laba dalam suatu periode

Kriteria perusahaan yang melakukan tindakan perataan laba adalah a) perusahaan dianggap melakukan praktik perataan laba apabila indeks perataan laba kurang dari 1 ( $\mathrm{CV} \Delta \mathrm{S}>\mathrm{CV} \Delta \mathrm{I})$, dan b) perusahaan dianggap tidak melakukan praktik perataan laba apabila indeks Eckel lebih besar/sama dengan $1(\mathrm{CV} \Delta \mathrm{S} \leq \mathrm{CV} \Delta \mathrm{I})$. Dalam hal ini, kelompok perusahaan yang melakukan praktik perataan laba diberi nilai 1 , sedangkan kelompok perusahaan yang tidak melakukan praktik perataan laba diberi nilai 0 (Eckel, 1981 dalam Budiasih, 2009).

Selanjutnya, Untuk melakukan menguji pengaruh profitabilitas, risiko keuangan dan nilai perusahaan baik secara parsial maupun simultan terhadap praktik perataan laba, maka dilakukan pengujian regresi dengan model persamaan berikut ini:

$$
\mathrm{I}=\alpha+\beta 1 \mathrm{ROA}+\beta 2 \mathrm{LEV}+\beta 3 \mathrm{PBV}+\varepsilon
$$

Keterangan :

RANKIS $=$ Peringkat perataan laba pada perusahaan diukur dengan Indeks Eckel

$\alpha=$ Konstanta

ROA = Rasio Return On Asset pada perusahaan

$\mathrm{LEV}=$ Rasio Financial Leverage perusahaan

$\mathrm{PBV}=$ Logaritma Rasio Price per Book Value perusahaan

$\varepsilon=$ error term

Berdasarkan deskripsi di atas maka model kerangka konseptual penelitian ditunjukan pada Gambar 1. 


\section{Gambar 1. Model Kerangka Konseptual}

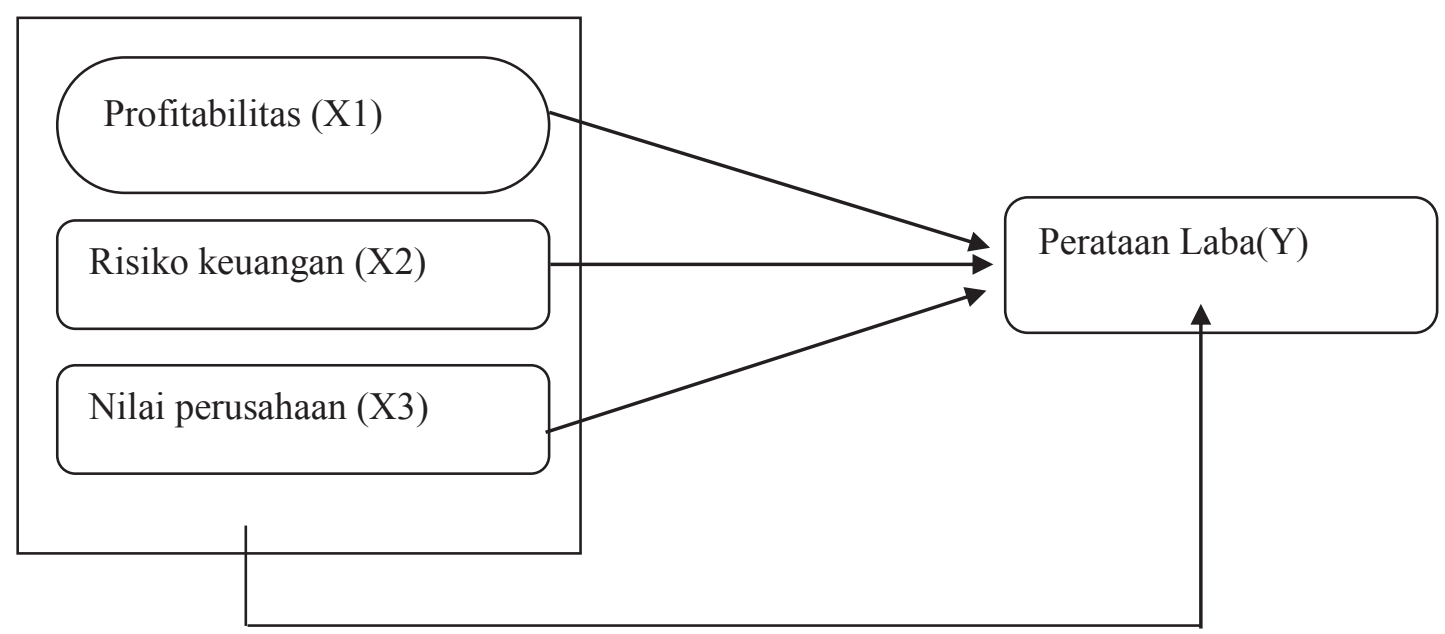

\section{HASIL DAN PEMBAHASAN}

Untuk mengetahui karakteristik data yang digunakan dalam penelitian ini, maka dilakukan uji statistik deskriptif yang hasilnya dapat dilihat pada Tabel 2.

Tabel 2. Hasil Uji Statistik Deskriptif

\begin{tabular}{llllll}
\hline & N & Minimum & Maximum & Mean & $\begin{array}{l}\text { Std. } \\
\text { Deviation }\end{array}$ \\
\hline Profitabilitas & 45 & 0,01539 & 0,40184 & 0,1160180 & 0,08440200 \\
Risiko Keuangan & 45 & 1,44277 & 4,96583 & 2,6166364 & 0,91459495 \\
Nilai Perusahaan & 45 & 0,01581 & 2,22789 & 0,2630040 & 0,49553436 \\
Perataan Laba & 45 & $-275,52732$ & 13,89073 & $-16,3735013$ & 70,29954768 \\
Valid N (listwise) & 45 & & & & \\
\hline
\end{tabular}

Sumber : Data diolah peneliti (2017)

Hasil analisis dengan Menggunakan statistik deskriptif terhadap profitabilitas (ROA) menunjukkan nilai terendah sebesar 0,015 dan nilai tertinggi sebesar 0,401. Rata-rata profitabilitas sebesar 0,116 . Hal ini berarti bahwa perusahaan sampel secara rata-rata mampu mendapatkan laba bersih hingga $11,6 \%$ dari total asetnya. Selanjutnya, Risiko Keuangan (leverage) menunjukkan nilai terendah sebesar 1,442 dan nilai tertinggi adalah sebesar 4,965. Rata-rata nilai leverage sebesar 2,616 nilai rata-rata di atas 0,50 menunjukkan bahwa pada perusahaan sampel cenderung memiliki hutang yang lebih besar dari modal sendirinya.

Nilai Perusahaan (PBV) menunjukkan nilai terendah adalah sebesar 0,015 dan nilai tertinggi adalah sebesar 2,227 serta rata-rata nilai PBV sebesar 0,263. perataan laba yang menggunakan indeks eckel menunjukkan nilai terendah sebesar -275,527 dan nilai tertinggi sebesar 13,890 dengan rata-rata sebesar -16,373. Hal ini berarti bahwa perusahaan sampel secara rata-rata melakukan perataan laba karena sebagaimana kriteria indeks eckel, bahwa perusahaan dianggap melakukan praktik perataan laba apabila indeks perataan laba kurang dari 1. 


\subsection{Hasil Analisis Regresi Linier Berganda}

Penelitian ini menggunakan uji regresi berganda untuk menguji pengaruh profitabilitas, risiko keuangan dan nilai perusahaan terhadap praktik perataan laba. Tabel 3 menunjukkan hasil pengujian secara parsial dan simultan profitabilitas, risiko keuangan dan nilai perusahaan terhadap praktik perataan laba.

Tabel 3. Ikhtisar Hasil Regresi Linier Berganda dan Pengujian Hipotesis

\begin{tabular}{|c|c|c|c|c|}
\hline \multicolumn{2}{|c|}{ Regresi Linier Berganda } & \multirow{2}{*}{$\begin{array}{l}\text { Standar } \\
\text { Error (e) }\end{array}$} & \multirow{2}{*}{$\begin{array}{l}\text { Std. Coeff. } \\
\text { Beta }(\boldsymbol{\beta})\end{array}$} & \multirow{2}{*}{$\begin{array}{l}\text { Prob. } \\
\text { Sig. } t\end{array}$} \\
\hline Model & $\boldsymbol{\beta}$ & & & \\
\hline Konstanta (Constant) & $-87,762$ & 36,349 & & 0,020 \\
\hline Profitabilitas $\left(\mathrm{X}_{1}\right)$ & 206,885 & 126,104 & 0,248 & 0,109 \\
\hline Risiko Keuangan $\left(\mathrm{X}_{2}\right)$ & 15,588 & 11,365 & 0,203 & 0,178 \\
\hline Nilai Perusahaan $\left(\mathrm{X}_{3}\right)$ & 25,091 & 21,526 & 0,177 & 0,251 \\
\hline Level of significance $(\alpha)$ & $=5 \%$ & & & \\
\hline Koefisien Korelasi (r) & $=0,329$ & & & \\
\hline Koefisien Determinasi $\left(\mathrm{R}^{2}\right)$ & $=0,108$ & & & \\
\hline Adjusted $\mathrm{R}^{2}$ & $=0,043$ & & & \\
\hline F-Hitung & $=1,661$ & & & \\
\hline Probabilitas (Sig. F) & $=0,190$ & & & \\
\hline
\end{tabular}

Sumber : Data diolah peneliti (2017)

persamaan regresi linier berganda pada Tabel 3 adalah:

$Y=-87,762+206,885 X_{1}+15,588 X_{2}+25,091 X_{3}+\varepsilon$

\subsubsection{Profitabilitas terhadap Perataan Laba}

Hasil pengujian $t$-test menunjukkan bahwa variabel independensi profitabilitas (ROA) terhadap perataan laba pada Tabel 5 dapat dilihat dari nilai signifikansi sebesar 0,109. Nilai signifikansi yang berada di atas $0,05(0,109<\mathrm{P})$ menunjukkan bahwa ROA tidak memiliki pengaruh yang signifikan terhadap perataan laba, sehingga Hipotesis 1 diterima. Profitabilitas (ROA) yang menggambarkan tingkat kinerja perusahaan menunjukkan tidak adanya pengaruh yang signifikan terhadap perataan laba. Hal ini menunjukkan bahwa perusahaan dengan profitabilitas yang rendah cenderung melakukan praktik perataan laba. Fluktuasi yang lebih banyak pada pelaporan laba mempunyai kemungkinan lebih besar terjadi pada perusahaan dengan tingkat profitabilitas rendah. Kondisi tersebut menimbulkan akibat negatif sebagai contoh fluktuasi yang berlebihan tersebut dapat menimbulkan kenaikan pada biaya modal atau menurunkan harga saham. Perusahaan-perusahaan dengan tingkat profitabilitas yang rendah cenderung untuk meratakan pelaporan labanya.

Penelitian ini konsisten dengan Aji dan Mita (2010) yang menyatakan semakin tinggi tingkat profitabilitas maka perusahaan akan cenderung untuk tidak melakukan perataan laba karena perusahaan tersebut akan semakin menjadi sorotan publik, sehingga perusahaan kemungkinan berusaha untuk tidak melakukan tindakan yang membahayakan kredibilitas perusahaan. Profitabilitas diproksi dengan ROA dan tidak memiliki pengaruh terhadap perataan 
laba diduga karena investor cenderung mengabaikan informasi ROA yang ada secara maksimal sehingga manajemen pun menjadi tidak termotivasi melakukan perataan laba.

\subsubsection{Risiko Keuangan terhadap Perataan Laba}

Berdasarkan hasil pengujian $t$-test mengenai pengaruh variabel risiko keuangan (leverage) terhadap perataan laba pada tabel 5 dapat dilihat dari nilai signifikansi sebesar 0,178 . Nilai signifikansi yang berada di atas 0,05 menunjukkan bahwa leverage tidak memiliki pengaruh yang signifikan terhadap perataan laba, sehingga Hipotesis 2 ditolak. Hasil pengujian ini tidak sesuai dengan penelitian yang dilakukan Cahyani (2012), bahwa adanya pengaruh risiko keuangan terhadap perataan laba yang semakin tinggi risiko keuangan maka perusahaan semakin cenderung untuk melakukan praktik perataan laba. Tidak berpengaruhnya risiko keuangan terhadap praktik perataan laba diduga adanya kebijakan hutang yang tidak terlalu ketat sehingga perusahaan mudah untuk memperoleh kredit dan manajer cenderung untuk tidak melakukan perataan laba.

Dugaan lain, kreditur minta laporan keuangan yang lebih dipercaya, oleh karenanya kreditur meningkatkan pengawasan yang lebih ketat dan melakukan tekanan kepada manajer sehingga manajer tidak memiliki kesempatan untuk melakukan manajemen laba. Perusahaan yang memiliki rasio hutang yang tinggi, maka manajemen menggunakan risiko yang bukan dalam bentuk rekayasa laba karena adanya pengawasan yang insentif dari kreditur. Ketika risiko perusahaan tinggi yang diukur dengan rasio hutang yang tinggi, maka manajemen berusaha untuk menurunkan risiko persepsi bagi kreditur dengan cara menyajikan laporan laba yang relatif lebih stabil, artinya manajer tidak melakukan rekayasa laba (Agustin dan Hermanto, 2015).

\subsubsection{Nilai Perusahaan terhadap Perataan Laba}

Hasil pengujian t-test dari variabel independen nilai perusahaan pada tabel 5 mempunyai nilai signifikan sebesar 0,251 . Nilai signifikan yang lebih besar dari 0,05 menunjukkan bahwa nilai perusahaan yang diproksikan dengan PBV tidak memiliki pengaruh signifikan terhadap perataan laba dan Hipotesis 3 ditolak. Ditolaknya hipotesis ini, menandakan bahwa nilai perusahaan tidak hanya tercermin dari harga saham, harus juga dilihat dari besarnya dividen yang dibagikan. Apabila dividen yang dibagikan besar maka tingkat nilai harga saham juga besar dan apabila dividen yang dibagikan kecil maka nilai harga saham juga kecil. Harga saham kecil tidak akan berpengaruh kepada praktik perataan laba. Hasill penelitian ini tidak sama dengan yang dilakukan Aji dan Mita (2010) yang menyatakan bahwa semakin tinggi nilai perusahaan maka perusahaan akan cenderung melakukan praktek perataan laba.

\subsubsection{Pengujian Hipotesis secara Silmutan}

Hasil pengujian pada tabel 5 menunjukkan bahwa nilai signifikan $\mathrm{F}$ sebesar 1,661 dengan tingkat probabilitas (sig. F) sebesar 0,190. Hal ini menunjukkan probabilitas hitung lebih besar dari level of significance yang berarti tidak terdapat pengaruh signifikan secara simultan variabel profitabilitas, risiko keuangan dan nilai perusahaan terhadap praktik perataan laba. Nilai Koefisien Determinasi $\left(R^{2}\right)$ sebesar 0,108 dengan Adjusted $R^{2}$ sebesar 0,043. Hal ini memberikan pengertian bahwa $4,3 \%$ perataan laba dapat dijelaskan oleh profitabilitas, risiko keuangan dan nilai perusahaan, sedangkan sisanya yaitu 95,7\% perataan laba dipengaruhi oleh variabel-variabel lain yang tidak diteliti dalam penelitian ini. Hasil penelitian ini tidak sama dengan yang dilakukan oleh Prayudi dan Daud (2013) yang menyimpulkan adanya hubungan signifikan secara simultan profitabilitas, risiko keuangan dan nilai perusahaan terhadap praktik perataan laba. 


\section{SIMPULAN, KETERBATASAN DAN KONTRIBUSI PRAKTIS}

Berdasarkan hasil dan pembahasan dapat disimpulkan bahwa (1) Profitabilitas (ROA) tidak memiliki pengaruh signifikan terhadap perataan laba, (2) Risiko keuangan (Leverage) tidak memiliki pengaruh signifikan teerhadap perataan laba, (3) Nilai perusahaan (PBV) tidak memiliki pengaruh signifikan terhadap perataan laba, dan (4) profitabilitas, risiko keuangan dan nilai perusahaan tidak bepengaruh secara signifikan terhadap praktik perataan.

Keterbatasan penelitian yang masih perlu menjadi bahan revisi penelitian selanjutnya, yaitu: (1) Rentang waktu yang digunakan dalam penelitian ini yaitu selama tiga tahun terlalu pendek. (2) Sampel yang digunakan hanya terbatas pada perusahaan manufaktur yang terdapat di BEI. (3) Dengan diperolehnya sedikit variabel yang memiliki pengaruh yang signifikan terhadap perataan laba, maka diperoleh masih besarnya pengaruh variabel lain diluar penelitian yang berperan dalam perilaku perataan laba oleh perusahaan (sebesar 95,7\%),. Sehingga tujuan dan fenomena penyebab dilakukannya perataan laba masih belum terjawab sepenuhnya.

Penelitian ini memberikan kontribusi praktis bagi manajemen sebagai dasar pertimbangan dalam memutuskan apakah perusahaan perlu melakukan praktik perataan laba. Bagi pihak investor penelitian ini diharapkan dapat memberikan informasi tambahan mengenai faktor yang berpengaruh terhadap tindakan perataan laba, sehingga pengguna laporan keuangan lebih mewaspadai laporan keuangan yang dihasilkan perusahaan.

\section{DAFTAR PUSTAKA}

Abiprayu, KB (2011) Pengaruh Profitabilitas, Ukuran Perusahaan Financial Leverage, Kualitas Audit, Dan Dividend Payout Ratio Terhadap Perataan Laba (Studi Kasus Pada Perusahaan Manufaktur Yang Terdaftar Di Bursa Efek Indonesia Tahun 2006-2009). Skripsi. Semarang: Universitas Dipenogoro.

Agustin, T Dan Hermanto, SB (2015) Pengaruh Nilai Perusahaan, Profitabilitas Dan Risiko Keuangan Terhadap Earnings Management. Jurnal Ilmu \& Riset Akuntansi. Vol. 4 No. $1: 1-19$.

Aji, DY Dan Mita, AF (2010) Pengaruh Profitabilitas, Nilai Perusahaan, Dan Struktur Kepemilikan Terhadap Praktik Perataan Laba: Studi Empiris Perusahaan Manufaktur Yang Terdaftar Di BEI Simposium Nasional Akuntansi. Makasar.

Amanza, AH (2012) Analisis Faktor-Faktor Yang Mempengaruhi Praktik Perataan Laba (Income Smoothing) Studi Empiris Pada Perusahaan Manufaktur Yang Terdaftar Di BEI Tahun 2006-2010. Skripsi. Semarang: Fakultas Ekonomika Dan Bisnis Universitas Diponegoro.

Atarwaman, R (2011) Analisis Pengaruh Ukuran Perusahaan, Profitabilitas Dan Kepemilikan Manejerial Terhadap Praktik Perataan Laba Yang Dilakukan Oleh Perusahaan Manufaktur. Jurnal Ilmu Ekonomi Advantage. Vol. 2. No. 2.

Bitner Dan Dolan (2010) Earnings Management And The Underperformance Of Seasoned Equity Offering. Journal Of Financial Economics. Vol. 50: 63-99.

Brigham, EF. Dan Joel FH (2011) Dasar-Dasar Manajemen Keuangan. Salemba Empat: Jakarta.

Budiasih, IGAN (2009) Faktor-Faktor Yang Mempengaruhi Praktik Perataan Laba. Audi Jurnal Akuntansi Dan Bisnis. Vol. 4 No. 1: 1-14. 
Cahyani, ND (2012) Pengaruh Profitabilitas, Risiko Keuangan, Nilai Perusahaan, Struktur Kepemilikan, Ukuran Perusahaan, Dan Jenis Industri Terhadap Praktik Perataan Laba Pada Perusahaan Yang Terdaftar Di Bei Periode Tahun 2005-2010. Juraksi. Vol. 1, No. 2.

Noviana, SR dan Yuyetta, E., (2011) Analisis Faktor-Faktor Yang Mempengaruhi Praktik Perataan Laba. Jurnal Akuntansi dan Auditing Vol. 8, No. 1.

Pratiwi, H Dan Handayani, BD (2014) Pengaruh Profitabilitas, Kepemilikan Manajerial Dan Pajak Terhadap Praktik Perataan Laba. Accounting Analysis Journal 3 (2) (2014): 264272.

Sartono, RA(2010) Manajemen Keuangan Teori Dan Aplikasi. Bpfe: Yogyakarta.

Setyani, AY Dan Liffa, R (2012) Tindakan Perataan Laba Pada Perusahaan Yang Terdaftar Di Bursa Efek Indonesia. Jrak, Volume 8, No.2:139-148.

Sudana, I Made (2011) Manajemen Keuangan: Perusahaanteori Dan Praktik. Penerbit Erlangga: Surabaya.

Suharli, M (2006) Pengaruh Profitability Dan Investment Opportunity Set Terhadap Kebijakan Dividen Tunai Dengan Likuiditas Sebagai Variabel Penguat (Studi Pada Perusahaan Yang Terdaftar Di Bursa Efek Jakarta Periode 2002-2003. Jurnal Akuntansi Dan Keuangan. Vol.9. No. 1. Mei: 9-17.

Van Hone (2007) Income Smoothing. Journal Of Accounting Research, Empericial Research In Accounting. Selected Studies 6 (Supplement): 101-116.

Watts, R.L. Dan Zimmerman. 1986. Positive Accounting Theory. Prentice Hall: New York.

Widodo, S (2011) Analisis Perataan Laba Dan Faktor-Faktor Yang Mempengaruhi Pada Perusahaan Manufaktur Di Bursa Efek Jakarta. Akmenika Upy. Vol. 7. 